\title{
Spatial variability of enthalpy in broiler house during the heating phase
}

\author{
Patrícia F. P. Ferraz ${ }^{1}$, Tadayuki Yanagi Junior ${ }^{1}$, Gabriel A. e S. Ferraz ${ }^{1}$, \\ Leonardo Schiassi ${ }^{1} \&$ Alessandro T. Campos ${ }^{1}$ \\ ${ }^{1}$ Universidade Federal de Lavras/Departamento de Engenharia. Lavras, MG. E-mail: patricia.ponciano@deg.ufla.br (Corresponding author); \\ yanagi@deg.ufla.br; gabriel.ferraz@deg.ufla.br; leonardo.schiassi@deg.ufla.br; campos@deg.ufla.br
}

\section{Key words: poultry farming thermal comfort geostatistics kriging chicks}

\begin{abstract}
A B S T R A C T
The thermal environment inside a broiler house has a great influence on animal welfare and productivity during the production phase. Enthalpy is a thermodynamic property that has been proposed to evaluate the internal broiler house environment, for being an indicator of the amount of energy contained in a mixture of water vapor and dry air. Therefore, this study aimed to characterize the spatial variability of enthalpy in a broiler house during the heating phase using geostatistics. The experiment was conducted in the spring season, in a commercial broiler house with heating system consisting of two furnaces that heat the air indirectly, in the first 14 days of the birds' life. It was possible to characterize enthalpy variability using geostatistical techniques, which allowed observing the spatial dependence through kriging maps. The analyses of the maps allowed observing problems in the heating system in regions inside the broiler house, which may cause a thermal discomfort to the animals besides productive and economic losses.
\end{abstract}

\section{Palavras-chave: \\ avicultura \\ conforto térmico \\ geoestatística \\ krigagem \\ pintinhos}

\section{Variabilidade espacial da entalpia em galpões avícolas na fase de aquecimento}

\section{R E S U M O}

Dentro de um galpão avícola o ambiente térmico exerce grande influência sobre o bem-estar e a produtividade dos animais, ao longo do ciclo de produção. A entalpia é uma propriedade termodinâmica que tem sido proposta para avaliação do ambiente interno de galpões de criação de frangos de corte por ser um indicador da quantidade de energia contida em uma mistura de vapor d'água e ar seco razão por que se objetivou, com o presente trabalho, caracterizar a variabilidade espacial da entalpia em um galpão de frangos durante a fase de aquecimento de pintinhos utilizando a geoestatística. O experimento foi conduzido na primavera, em um galpão comercial com sistema de aquecimento constituído de duas fornalhas de aquecimento indireto do ar, durante os primeiros 14 dias de vida das aves. Utilizando as técnicas da geoestatística foi possível caracterizar a magnitude da variabilidade espacial da entalpia permitindo a observação da dependência espacial por meio de mapas de krigagem. A análise dos mapas permitiu observar a existência de falhas no sistema de aquecimento em regiões do galpão, que podem ser possíveis causadoras de desconforto térmico para os animais, além de perdas produtivas e econômicas. 


\section{INTRODUCTION}

Due to the current existing demands, the poultry production system in Brazil has searched for knowledge and techniques that aim to favor the maximum productivity of meat with the lowest cost (Ponciano et al., 2011). In the first days after hatching, chicks still do not have mature thermoregulatory systems or enough energy reserve to be able to adapt to adverse environmental conditions, which cause their body temperature to suffer variations according to the thermal conditions of the environment. According to Cordeiro et al. (2010), the first weeks of a bird's life are the most critical and mistakes made in this stage cannot be properly corrected in the future.

According to Barbosa Filho et al. (2007), enthalpy (H) has been proposed for the evaluation of internal environments of broiler houses. By definition, $\mathrm{H}$ is a thermodynamic quantity that indicates the amount of energy contained in a mixture of water vapor and dry air $\left(\mathrm{kJ} \mathrm{kg}^{-1}\right.$ dryair). Therefore, in cases of alteration of relative humidity for a same air temperature, the energy involved in the process changes and, consequently, the thermal exchanges in the environment are altered (Rodrigues et al., 2010).

Homogeneity of variables inside the houses in a production environment are expected and, according to Yanagi Júnior et al. (2011), these variables can be evaluated through spatialization, such as using geostatistical techniques. In this context, this study aimed to analyze the structure and magnitude of enthalpy spatial variability in a broiler house during the heating phase of chicks, using geostatistics, through the analysis of semivariograms, and the construction of isoline maps, through interpolation by kriging.

\section{Material ANd Methods}

The field experiment was carried out in a broiler house of a commercial broiler farm, in the western mesoregion of Minas Gerais, Brazil, during the spring of 2010. The mean geographic coordinates of the broiler house are $20^{\circ} 12^{\prime} 02^{\prime \prime} \mathrm{S}$ and $45^{\circ} 02^{\prime} 08^{\prime \prime}$ $\mathrm{W}$ of Greenwich. The climate in the region is characterized as mild temperate climate, with moderate temperatures, hot and rainy summer, classified by Köppen as Cwa (Sá Júnior et al., 2012).

The broiler house is oriented in the Northeast-Southwest direction, $13 \mathrm{~m}$ wide, $160 \mathrm{~m}$ long, with ceiling height of $3 \mathrm{~m}$, covered by $6-\mathrm{mm}$-thick fiber-cement tiles, with concrete floor, rice husk litter, side curtains and top cover made of yellow plastic canvas, positioned at a height of $2.45 \mathrm{~m}$. Double curtains were used on the sides of the house (one internal and another external). Internal curtains were removed when the birds were five days old and the external ones were managed according to the climatic conditions, along the entire experimental period.

The internal environment of the house was heated by two handmade furnaces with indirect air heating, made of bricks, clay and manure on an iron structure, which used biomass (firewood) as fuel. The furnaces were located $40 \mathrm{~m}$ distant from each other. Each one was $1.88 \mathrm{~m}$ long, $1.27 \mathrm{~m}$ wide and $1.58 \mathrm{~m}$ high. A three-phase motor, with power of $2206 \mathrm{~W}$ and $1725 \mathrm{rpm}$, was used to insufflate heated air into the house through a $10-\mathrm{cm}$-diameter metal tube.
The internal area of the house was limited by plywood sheets so that chicks remained as close as possible to the heating systems. As the animals grew, these sheets were moved in order to increase the available area. At the beginning of the experiment, on the first day of life, the birds were distributed at a density of 54 birds $\mathrm{m}^{-2}$; then, the useful area of the houses increased in order to reduce the stocking density, gradually, until 13 birds $\mathrm{m}^{-2}$ at the end of the heating phase.

The house contained 28,000 male Cobb chicks from 1 to 14 days old and the birds had access to water ad libitum along the entire experimental period. The diets supplied to the animals were formulated to meet the requirements of nutrients for the different growth phases. A continuous lighting program was adopted, according to Abreu et al. (2011).

For the characterization of the thermal environment inside the house, the measurements of dry-bulb temperature $\left(\mathrm{t}_{\mathrm{db}}\right)$, dew point temperature $\left(t_{d p}\right)$ and relative air humidity $(\mathrm{RH})$ were performed at a height compatible with the zone occupied by the birds, at $10.0 \mathrm{~cm}$ from the litter (Cordeiro et al., 2010), in intervals of five minutes, from 8 to 10 a.m. Temperature and relative air humidity were measured using sensors (Hobo Pro Series - Onset $^{\circledast}$ ), with precision of $\pm 3 \%$ of the reading, and $\mathrm{H}$ was then calculated using the equation developed by Albright (1990), which, according to Rodrigues et al. (2010), is the most reliable equation for animal environment studies.

$$
\mathrm{H}=1.006+\mathrm{W}\left(2501+1.805 \mathrm{t}_{\mathrm{db}}\right)
$$

where:

$\mathrm{H} \quad$ - enthalpy, $\mathrm{kJ} \mathrm{kg}^{-1}$ dryair;

$\mathrm{W}$ - mixture ratio, $\mathrm{kJ} \mathrm{kg}^{-1}$ dryair; and,

$\mathrm{T}_{\mathrm{db}} \quad$ - dry-bulb temperature, ${ }^{\circ} \mathrm{C}$.

For the spatialization of sensors and in order to map $\mathrm{H}$, a geographic coordinate $(\mathrm{m})$ was selected for the house; its initial point, the coordinate $(0 ; 0)$ was located on the West end and the final point was given by the coordinate $(13 ; 160)$, positioned on the East end. The indirect air-heating furnaces were located at the coordinates $(6.5 ; 60)$ and $(6.5 ; 100)$.

The positions of the sensors changed as the position of the plywood sheets changed, in order to always represent the conditions to which the birds were subjected along the experiment, as illustrated in Figure 1.

Since $\mathrm{L}$ is the width of the area available to the birds and $\mathrm{C}$ is the length, the position of the containing sheets was established

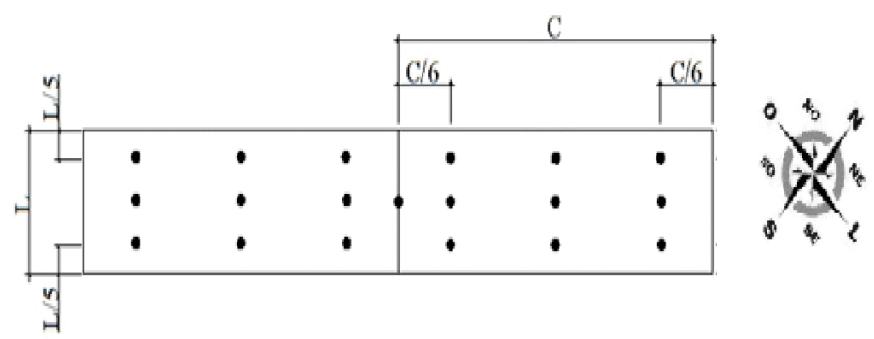

- Sensors/recorders of $\mathrm{t}_{\mathrm{db}}, \mathrm{t}_{\mathrm{dp}}$ and RH

Figure 1. Scheme of the position of sensors/recorders of drybulb temperature $\left(\mathrm{t}_{\mathrm{db}}\right)$, dew point temperature $\left(\mathrm{t}_{\mathrm{dp}}\right)$ and relative air humidity $(\mathrm{RH})$ in the broiler houses 
on the first day of life of the chicks and changed on the sixth, eighth and fourteenth days.

The spatial dependence of $\mathrm{H}$ in the broiler house during the heating phase of the chicks was analyzed through fits of semivariograms and interpolation by ordinary kriging. The classical semivariogram was estimated using Eq. 2:

$$
\hat{\gamma}(h)=\frac{1}{2 N(h)} \sum_{i=1}^{N(h)}\left[Z\left(x_{i}\right)-Z\left(x_{i}+h\right)\right]^{2}
$$

where:

$\mathrm{N}(\mathrm{h})$ - number of experimental pairs of observation $\mathrm{Z}\left(\mathrm{x}_{\mathrm{i}}\right)$; and,

$\mathrm{Z}\left(\mathrm{x}_{\mathrm{i}}+\mathrm{h}\right)$ separated by a distance $\mathrm{h}$.

The semivariogram is represented by the graph of $\hat{\gamma}(\mathrm{h})$ versus h. From the fit of a mathematical model to the calculated values of $\hat{\gamma}(\mathrm{h})$, the coefficients of the theoretical model for the semivariogram were calculated: nugget effect $(\mathrm{C} 0)$, sill value $(\mathrm{C} 0+\mathrm{C} 1)$ and range $(\mathrm{a})$, as described by Bachmaier \& Backers (2011).

The semivariogram was fitted using the Residual Maximum Likelihood (REML) method, which in general results in less biased estimates for small samplings, according to Diggle \& Ribeiro Júnior (2007) and Kerry \& Oliver (2007). According to Marchant \& Lark (2007), this method estimates the random and deterministic components of the variation with smaller bias, besides using combinations of data instead of using the original data. The spherical mathematical model was used for the fit of the semivariogram, which is widely used in geostatistical studies.

In order to know the quality of the fit, the degree of spatial dependence (DSD) of the attributes was used, as proposed by Cambardella et al. (1994), which classify semivariograms as follows: nugget effect $<25 \%$ of the sill - strong spatial dependence; nugget effect between 25 and $75 \%$ - moderate spatial dependence; and nugget effect $>75 \%$ - weak spatial dependence.

Another way of evaluating estimation quality and the fit of the semivariograms is through validation. According to Isaaks \& Srivastava (1989), validation is the technique of evaluation of estimate errors that allows comparing predicted and sampled values. It is possible to obtain some values very useful for the choice and observe estimation quality and the fit of the semivariogram, such as: mean error (ME), which must be as close as possible to zero; standard deviation of mean error $\left(\mathrm{SD}_{\mathrm{ME}}\right)$, which must be as low as possible; reduced mean error (RME), which must show values close to zero, and standard deviation of reduced mean errors $\left(\mathrm{SD}_{\mathrm{RME}}\right)$, which must be as close as possible to one.

After the fit of the semivariograms, the data were interpolated by ordinary kriging in order to allow the visualization of spatial distribution patterns of enthalpy inside the broiler house during the heating phase. Kriging is the interpolation method used in geostatistics to predict the value of a variable of a non-sampled site through information obtained from sampled data and with spatial dependence expressed by the semivariogram between the neighboring samplings (Isaaks \& Srivastava, 1989).

Geostatistical analysis and the plotting of the maps were performed using the $\mathrm{R}$ statistical program ( $\mathrm{R}$ Development Core Team, 2014), through the geoR package (Ribeiro Júnior \& Diggle, 2001).

\section{Results AND Discussion}

According to the geostatistical analyses, all studied days showed spatial variability of $\mathrm{H}$ inside the broiler house, expressed by the semivariogram (Table 1). This result allows inferring that, during the analyzed period, the heating system was not working in such a way to guarantee the homogeneity of the spatial distribution of this variable inside the house.

The nugget effect $\left(\mathrm{C}_{0}\right)$ is an important parameter and indicates unexplained variability, considering the used sampling distance. Since it is possible to quantify the individual contribution of these errors, the nugget effect can be expressed as percentage of the sill, thus facilitating the comparison of the DSD of the studied variables (Trangmar et al., 1985) (Table 1). According to the classification of Cambardella et al. (1994), the semivariograms fitted to days 1 and 13 have moderate DSD, while the others have strong DSD.

The values of range (a) relative to the semivariograms have considerable relevance in the determination of the limit

Table 1. Method, model and estimated parameters of the experimental semivariograms for enthalpy inside the house as a function of the age of the chicks

\begin{tabular}{|c|c|c|c|c|c|c|c|c|c|c|c|}
\hline Day & Method & Model & $\mathrm{C}_{0}$ & $C_{1}$ & $\overline{C_{0}+C_{1}}$ & a & DSD & ME & $\mathbf{S D}_{\mathrm{ME}}$ & RME & $S D_{\text {RME }}$ \\
\hline 1 & REML & Spherical & 7.627 & 21.902 & 29.529 & 2.104 & 25.829 & 0.000 & 0.000 & 5.822 & 1.035 \\
\hline 2 & REML & Spherical & 0.000 & 17.219 & 17.219 & 2.301 & 0.000 & 0.000 & 0.000 & 4.469 & 1.038 \\
\hline 3 & REML & Spherical & 1.526 & 8.524 & 10.050 & 2.328 & 15.184 & 0.000 & 0.000 & 3.414 & 1.038 \\
\hline 4 & REML & Spherical & 3.465 & 14.916 & 18.381 & 2.399 & 18.851 & 0.000 & 0.000 & 4.617 & 1.038 \\
\hline 5 & REML & Spherical & 2.579 & 34.153 & 36.732 & 3.811 & 7.021 & -0.001 & 0.000 & 6.346 & 1.034 \\
\hline 6 & REML & Spherical & 0.891 & 33.472 & 34.363 & 2.400 & 2.594 & 0.000 & 0.000 & 6.281 & 1.035 \\
\hline 7 & REML & Spherical & 4.689 & 23.314 & 28.003 & 5.855 & 16.745 & -0.024 & -0.002 & 5.175 & 1.036 \\
\hline 8 & REML & Spherical & 0.449 & 14.827 & 15.276 & 4.381 & 2.940 & 0.004 & 0.000 & 4.104 & 1.028 \\
\hline 9 & REML & Spherical & 7.638 & 26.727 & 34.365 & 10.179 & 22.226 & -0.061 & -0.004 & 6.014 & 1.057 \\
\hline 10 & REML & Spherical & 0.000 & 20.427 & 20.427 & 3.224 & 0.000 & 0.000 & 0.000 & 4.802 & 1.031 \\
\hline 11 & REML & Spherical & 0.000 & 16.364 & 16.364 & 3.315 & 0.000 & 0.000 & 0.000 & 4.298 & 1.031 \\
\hline 12 & REML & Spherical & 6.982 & 27.362 & 34.344 & 4.761 & 20.330 & 0.026 & 0.002 & 6.166 & 1.031 \\
\hline 13 & REML & Spherical & 31.434 & 33.822 & 65.256 & 3.285 & 48.170 & 0.000 & 0.000 & 8.527 & 1.027 \\
\hline 14 & REML & Spherical & 1.343 & 9.209 & 10.552 & 3.900 & 12.727 & 0.000 & 0.000 & 3.439 & 1.029 \\
\hline
\end{tabular}

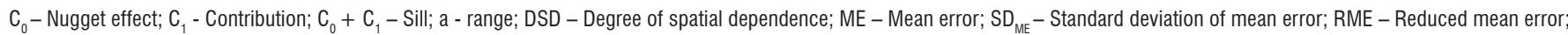
$\mathrm{SD}_{\mathrm{RME}}$ - Standard deviation of reduced mean error; REML - Residual Maximum Likelihood 


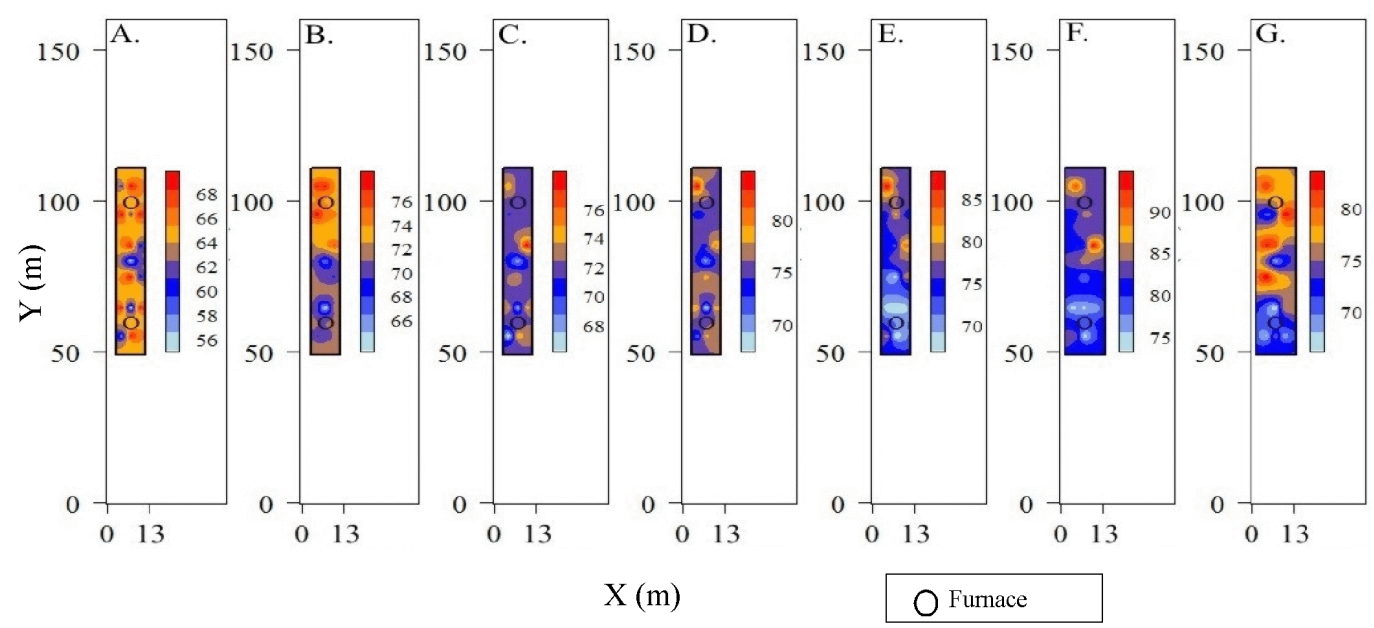

Figure 2. Spatial distribution of enthalpy on days 1 (A), 2 (B), 3 (C), 4 (D), 5 (E), 6 (F) and 7 (G) $\left(\mathrm{kJ} \mathrm{kg}^{-1}\right.$ dryair)

of spatial dependence, i.e., they indicate to what extent the variable is influenced by the space; in the present study, the range varied from $2.01 \mathrm{~m}$ (on the first day) to $10.18 \mathrm{~m}$ (on the ninth day).

Figure 2 illustrates the spatial distribution of $\mathrm{H}\left(\mathrm{kJ} \mathrm{kg}^{-1} \mathrm{dryair}\right)$ from the first to the seventh day of life of the chicks. There was great variability of $\mathrm{H}$ inside the house; regions with low $\mathrm{H}$ are characterized by more bluish colors, while regions with high $\mathrm{H}$ show more reddish colors. Figure 2 indicates an inefficiency of the adopted heating system, at both heating the environment and maintaining such heating uniformly.

According to the thermal conditions to which the chicks were subjected during the studied period, $\mathrm{H}$ varied from 56 to $90 \mathrm{~kJ} \mathrm{~kg}^{-1}$ dryair in the first week of life. Ponciano et al. (2012) claim that, in the first week of life, the ideal values of $\mathrm{H}$ range from 73 to approximately $102 \mathrm{~kJ} \mathrm{~kg}^{-1}$ dryair. Figure 3 shows the frequency of occurrence of $\mathrm{H}$ values along the broiler house, obtained after interpolation by kriging.

According to Figures 2 and 3, it can be claimed that on the first day of life, along the entire house, chicks were subjected to $\mathrm{H}$ conditions below the recommended as ideal for this age range. On the second and third day, this situation remained critical and the birds were subjected to conditions of $\mathrm{H}$ below the recommendation in about 72 and $93 \%$ of the house area, respectively. From the fourth to the seventh studied day, $\mathrm{H}$

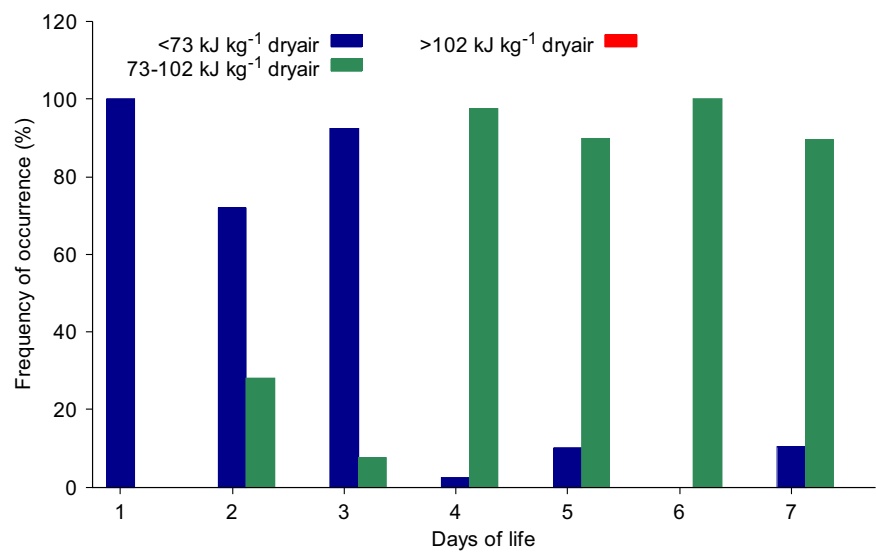

Figure 3. Frequency of occurrence (\%) of enthalpy intervals in the classes below, ideal and above the recommended for the first week of life, obtained after interpolation by kriging values were higher and closer to the ideal, while on the sixth day of life (Figure 2F) H values within the recommended interval were observed in the entire house. However, based on the light blue points in the maps in Figure 2D, 2E and 2G, it is still evident that $\mathrm{H}$ values remained below that considered as comfortable. Additionally, it is notorious that these light blue points are close to the coordinates $(6.5 ; 60)$, which indicate the position of one of the furnaces, evidencing a failure in this heating system.

According to Menegali et al. (2010), the control of the thermal environment inside the facilities in which the birds are housed must be greater during the first weeks of life, because exposing the animals to such uncomfortable situation may compromise the formation of the thermoregulatory system, cause the development of diseases in the respiratory system and harm the development and productivity of the birds, especially during the initial life period of the chicks (Cordeiro et al., 2011). In addition, according to the same author, due to the intensity of the stress suffered by these animals, these failures may not be satisfactorily corrected, which may compromise the entire production phase.

As to the second week of life and according to Ponciano et al. (2012), the chicks must be maintained in environments with $\mathrm{H}$ values between 60 and $101 \mathrm{~kJ} \mathrm{~kg}^{-1}$ dryair. Based on Figures 4 and $5, \mathrm{H}$ values varied from 55 to $90 \mathrm{~kJ} \mathrm{~kg}^{-1}$ dryair. For the studied period and despite the great data variability, only on the $12^{\text {th }}$ and $13^{\text {th }}$ days of life there were points inside the house with $\mathrm{H}$ below the recommended, in 0.11 and $40.5 \%$ of the house area, respectively, i.e., in the second week of life, the chicks were subjected to the condition of thermal comfort in most of the time.

According to Carvalho et al. (2014), broiler production is achieved when the animals are raised in a thermally adequate environment, in which there is no need to spend energy to compensate for thermal discomfort, either by cold or heat. According to Nääs et al. (2001), the use of environmental evaluations allows determining the reflex of the discomfort in the flock of birds due to situations adverse to the thermal comfort zone recommended by the literature. In many moments during the studied period, the values of $\mathrm{H}$ obtained in the environment remained out of the comfort zone for the 


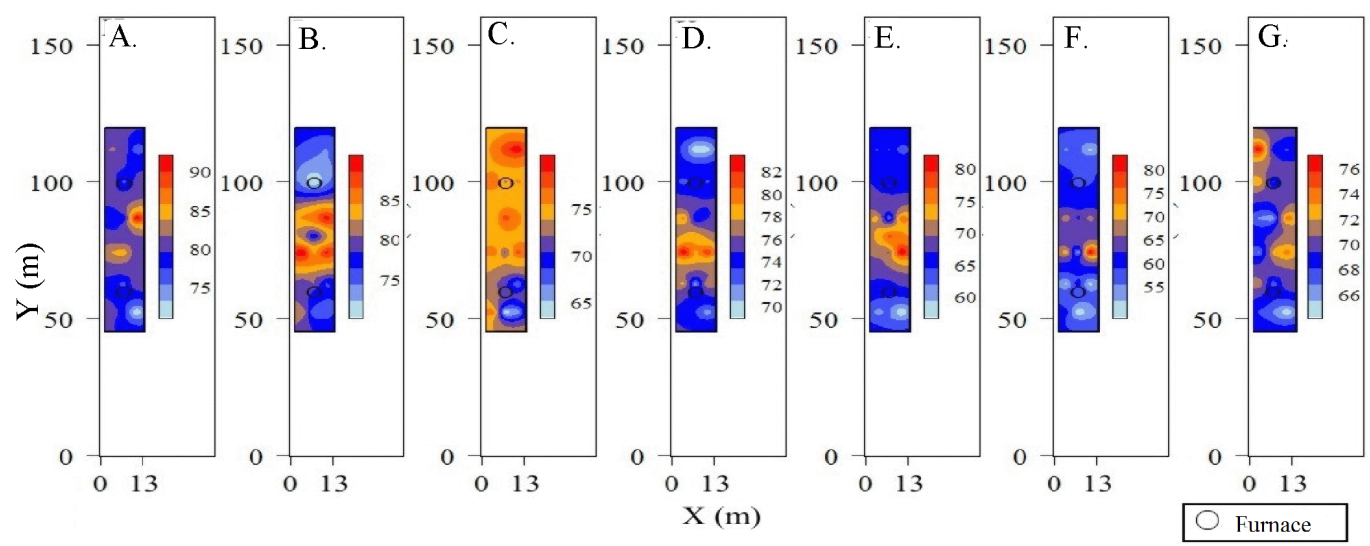

Figure 4. Spatial distribution of enthalpy on days 8 (A), 9 (B), 10 (C), 11 (D), 12 (E), 13 (F) and 14 (G) (kJ kg-1 dryair)

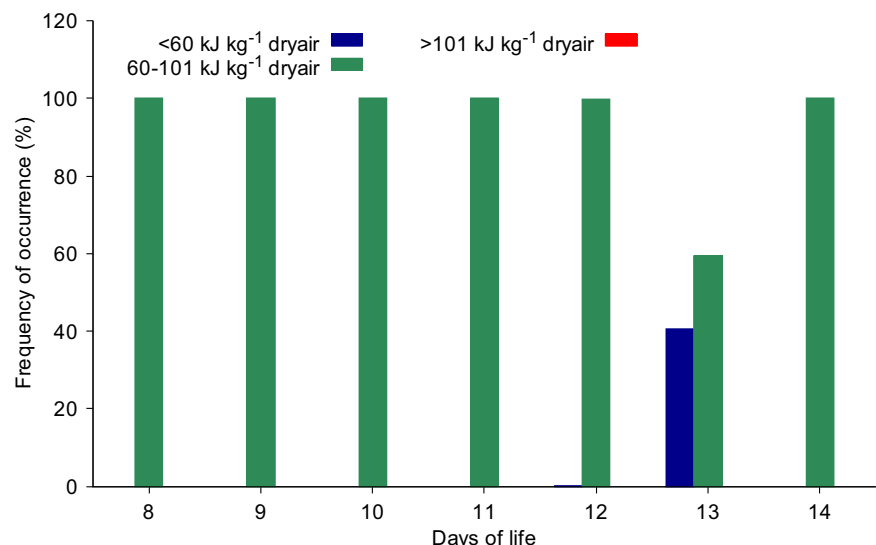

Figure 5. Frequency of occurrence (\%) of enthalpy intervals in the classes below, ideal and above the recommended for the second week of life, obtained after interpolation by kriging

birds; thus, it can be assumed that it was evident the occurrence of inadequate and stressful situations for the birds, which are the probable causes of productive and economic losses in the studied flock of animals.

\section{Conclusions}

1. The semivariograms allowed the characterization of the magnitude of spatial variability of enthalpy inside the studied broiler house.

2. It was possible to make isoline maps that allowed the observation of spatial variability, from the interpolation by kriging.

3. It was also possible to identify the nonuniformity of enthalpy distribution inside the broiler house.

4. The maps also allowed observing the existence of failures in the heating system in some regions of the broiler house, which may cause discomfort to the animals productive and economic losses.

\section{ACKNOWLedgments}

The authors thank the National Council for Scientific and Technological Development (CNPq), the Minas Gerais Research Foundation (FAPEMIG) and the Coordination for the Improvement of Higher Education Personnel (CAPES), for the financial support.

\section{Literature Cited}

Abreu, V. M. N.; Abreu, P. G. de; Coldebella, A.; Jaenisch, F. R. F.; Santos Filho, J. I. dos; Paiva, D. P. de. Curtain color and lighting program in broiler production: I - General performance. Revista Brasileira de Zootecnia, v.40, p.2026-2034, 2011. http://dx.doi. org/10.1590/S1516-35982011000900026

Albright L. D. Environment control for animals and plants. St. Joseph: American Society of Agricultural Engineers Michigan, 1990. 453p. ASAE textbook

Bachmaier, M.; Backes, M. Variogram or semivariogram? Allan variance or introducing a new term? Mathematical Geosciences, v.43, p.735740, 2011. http://dx.doi.org/10.1007/s11004-011-9348-3

Barbosa Filho, J. A. D.; Silva, I. J. O.; Silva, M. A. N.; Silva, C. J. M. Avaliação dos comportamentos de aves poedeiras utilizando sequência de imagens. Engenharia Agrícola, v.27, p.93-99, 2007. http://dx.doi.org/10.1590/S0100-69162007000100002

Cambardella, C. A.; Moorman, T. B.; Novak, J. M.; Parkin, T. B.; Karlen, D. L.; Turco, R. F.; Konopka, A. E. Field scale variability of soil properties in Central Iowa soils. Soil Science Society of America Journal, v.58, p.1501-1511, 1994. http://dx.doi. org/10.2136/sssaj1994.03615995005800050033x

Carvalho, C. da C. S.; Santos, T. C dos; Silva, G. C. da; Santos, L. V.; Moreira, S. J. M.; Botelho, L. F. R. Conforto térmico animal e humano em galpões de frangos de corte no semiárido mineiro. Revista Brasileira de Engenharia Agrícola e Ambiental, v.18, p.769-773, 2014. http://dx.doi.org/10.1590/S1415-43662014000700015

Cordeiro, M. B.; Tinôco, I. de F. F.; Mesquita Filho, R. M. de; Sousa, F. C. Análise de imagens digitais para a avaliação do comportamento de pintainhos de corte. Engenharia Agrícola, v.31, p.418-426, 2011.

Cordeiro, M. B.; Tinôco, I. de F. F.; Silva, J. N. da; Vigoderis, R. B.; Pinto, F. de A. de C.; Cecon, P. R. Conforto térmico e desempenho de pintos de corte submetidos a diferentes sistemas de aquecimento no período de inverno. Revista Brasileira de Zootecnia, v.39, p.217224, 2010. http://dx.doi.org/10.1590/S1516-35982010000100029

Diggle, P. J.; Ribeiro Júnior, P. J. Model based geostatistics. New York: Springer. 2007. 230p.

Isaaks, E. H.; Srivastava, R. M. An introduction to applied geostatistics. New York: Oxford University, 1989. 56p.

Kerry, R.; Oliver, M. A. Sampling requirements for variograms of soil properties computed by the method of moments and residual maximum likelihood. Geoderma. v.140, p.383-396, 2007. http:// dx.doi.org/10.1016/j.geoderma.2007.04.019 
Marchant, B. P.; Lark, R. M. Robust estimation of the variogram by residual maximum likelihood. Geoderma, v.140, p.62-72, 2007. http://dx.doi.org/10.1016/j.geoderma.2007.03.005

Menegali, I.; Baeta, F. C.; Tinoco, I. de F. F.; Cordeiro, M. B.; Guimarães, M. C. C. Desempenho produtivo de frangos de corte em diferentes sistemas de instalações semiclimatizadas no sul do Brasil. Engenharia na Agricultura, v.18, p.461-471, 2010.

Nääs, I. A.; Miragliotta, M. Y.; Aradas, M. E. C.; Silva, I. J. O.; Baracho, M. S. Controle e sistematização em ambientes de produção. In: Silva, I. J. O. (ed.). Ambiência na produção de aves em clima tropical. 1.ed. Piracicaba: FUNEP, 2001. v.1, 2001. p.165-200.

Ponciano, P. F.; Lopes, M. A.; Yanagi Júnior, T.; Ferraz, G. A. S. Análise do ambiente para frangos por meio da lógica Fuzzy: Uma revisão. Archivos de Zootecnia, v.60, p.1-13. 2011.

Ponciano, P. F.; Yanagi Júnior, T.; Lima, R. R. de; Schiassi, L.; Teixeira, V. H.. Adjust of regression models to estimate the rectal temperature of broilers for the first 14 days of life. Engenharia Agrícola, v.32, p.10-20, 2012. http://dx.doi.org/10.1590/S010069162012000100002
R Development Core Team. R: A language and environment for statistical computing. Vienna: R Foundation for statistical computing, 2014. <http://www.R-project.org/>. 22 Ago. 2014.

Ribeiro Júnior, P. J.; Diggle, P. J. GeoR: A package for geostatistical analysis. R-News, v.1, p.14-18, 2001.

Rodrigues, V. C.; Silva, I. J. O.; Vieira, F. M. C.; Nascimento, S. T. A correct enthalpy relationship as thermal comfort index for livestock. International Journal Biometeorology, v.55, p.455-459, 2010. http://dx.doi.org/10.1007/s00484-010-0344-y

Sá Júnior, A.; Carvalho, L. G.; Silva, F. F.; Alves, M.C. Applicaion of the Köppen classification for climatic zoning in the state of Minas Gerais, Brazil. Theoretical and Applied Climatology, v.108, p.1-7, 2012. http://dx.doi.org/10.1007/s00704-011-0507-8

Trangmar, B. B.; Yost, R. S.; Uehara, G. Applications of geostatistics to spatial studies of soil properties. Advances in Agronomy, v.38, p.45-94, 1985. http://dx.doi.org/10.1016/S0065-2113(08)60673-2

Yanagi Júnior, T.; Amaral, A. G.; Teixeira, V. H.; Lima, R. R. Caracterização espacial do ambiente termoacústico e de iluminância em galpão comercial para criação de frangos de corte. Engenharia Agrícola, v.31, p.1-12, 2011. http://dx.doi.org/10.1590/ S0100-69162011000100001 